\title{
PEMBAJAKAN PRODUK: PROBLEMA, STRATEGI DAN ANTISIPASI STRATEGI
}

\author{
Anas Hidayat \\ Fakultas Ekonomi Universitas Islam Indonesia \\ Katherine Mizerski \\ School of Marketing, Edith Cowan University \\ Western Australia
}

\begin{abstract}
Pemakaian 'merek' dalam dunia perdagangan telah dilakukan sejak jaman Yunani kuno. Demikian pula peniruan atau pembajakan terhadap produk bermerek. Di abad pertengahan, ancaman sangsi terhadap pelanggaran penggunaan merek juga telah dilakukan, misalnya ancaman hukuman gantung bagi para pelaku pembajakan.

Di era bisnis modern, bisnis produk bajakan menjadi semakin merajalela dengan skala internasional. Kerjasama internasional antar Negara telah dilakukan dalam menggalang pemberantasan dengan menghasilkan produk-produk hukum penangkalnya. Demikian pula upaya pemerintah domestik masing-masing negara di dunia di bawah koordinasi WTO, telah dan sebagian masih dalam proses menerapkan hukum perlindungan HKI. Misalnya Indonesia mencanangkan pemberlakuan UU HKI sejak tahun 2000.

Meskipun penelitian di bidang pembajakan produk sudah mulai mendapatkan apresiasi dari para ahli, namun penelitian yang dikaitkan dengan ilmu pemasaran masih tergolong baru, dan hasilnya masih bersifat sporadis, belum menemukan konsep teori yang kuat, baik penelitian pada sisi permintaan maupun sisi penawaran produk. Penelitian sisi penawaran memang lebih dahulu mendapatkan perhatian dari para ahli dengan mengindentifikasikan strategi masuk pasar para pembajak dan memformulasikan anti strategi pembajakan produk. Namun anti strategi pembajakan produk belum menunjukkan hasil yang efektif, jika dilihat dari kenyataan di lapangan bahwa pembajakan masih merajalela, terutama di pasar Asia (Callan 1998).
\end{abstract}

Kata Kunci: Pembajakan produk, strategi pembajakan, strategi anti pembajakan

HAM Prof Abdul Bari Azed SH MH, Dirjen HKI Departeman Kehakiman Rl:

'Peraturan perundang-undangan di bidang Hak Kekayaan Intelektual (HKI) sudah lengkap, namun penegakan hukumnya masih sangat lemah. Akibatnya, pembajakan terhadap HKI terus meningkat. Bila hal itu dibiarkan, terutama dalam konteks perkembangan global, Indonesia bisa diembargo negara-negara maju yang merasa produknya banyak dibajak' (Kedaulatan Rakyat, 07 Juli 2003)

PENDAHULUAN

Banyak definisi yang berkaitan dengan pembajakan produk seiring dengan perkembangan teknologi yang sangat pesat. Kemampuan inovasi pembajak juga semakin kreatif dengan dibantu kemampuan teknologi. Dalam terminology internasioal, istilah pembajakan produk bermacammacam. Misalnya: counterfeiting, piracy, imitation, grey product dan softlifting. Secara umum, pembajakan produk didefinisikan sebagai upaya mengkopi/memalsu produk, bungkus dan konfigurasi yang berkaitan 
dengan produk tersebut, sehingga seperti produk aslinya, serta memasarkannya untuk keuntungan sendiri (Lynch, 2002).

Menjual dan memproduksi produk bajakan adalah suatu tindakan kriminal karena telah melakukan pelanggaran HKI (Cordell et al., 1996). Dalam satu dasawarsa terakhir, penegakan Hak Kekayaan Intelektual (HKI) atau Intellectual Property Rights (IPR) menjadi bagian yang sangat penting dalam bisnis internasional karena semakin banyak produk-produk yang berkaitan dengan HKI menjadi komoditas dunia. Produk yang berkaitan dengan HKI ini tidak lepas dengan perkembangan teknologi dunia yang sangat pesat, sehingga mendorong kemampuan berinovasi manusia juga semakin tinggi. Di samping itu produk yang berkaitan dengan HKI juga memiliki nilai tambah yang sangat besar sehingga mempercepat pula kemampuan pengusaha mengeruk keuntungan besar dan mempercepat pengembalian modal investasi. Banyak produk yang berkaitan dengan $\mathrm{HKI}$ memiliki 'brand' dan 'image' yang berasosiasi dengan budaya pop (pop culture), terutama produk-produk dari Amerika Serikat, seperti Coca Cola, Polo, Nike, Adidas, McDonald, dan Marlboro. Produk-produk tersebut menjadi target para pembajak untuk mengeruk keuntungan dengan mendompleng nama besar produk tersebut. Ulah para pembajak juga merambah pada produk-produk farmasi yang memiliki keterkaitan langsung terhadap keselamatan manusia (Shultz II \& Saporito 1996). Produk farmasi ini nampaknya menjadi target yang popular bagi pembajak. Chaudhry \& Walsh (1995) menyebutkan angka 5\% dari total penjualan dunia produk farmasi dibajak, dan hampir $70 \%$ produk farmasi yang dijual di Negara berkembang dalam bentuk produk bajakan.

Pembajakan memang marak di negara berkembang, dengan porsi yang terbesar ada di Asia (Callan, 1998). Upaya penangkal dari pemerintah setempat telah dilakukan dengan memberlakukan peraturan yang melindungi $\mathrm{HKI}$ dan kesungguhan memberikan sangsi kepada pelaku pelanggran HKI. Namun pemberlakuan hukum yang berkaitan dengan HKI tidak standar satu dengan lainnya, sehingga pemberlakuan penegakan hukum juga berbeda-beda. Misalnya China, Singapura, dan Indonesia telah memberlakukan UU HKI dengan sangsi yang keras, tetapi aktifitas pembajakan nampaknya tidak pernah surut di ketiga Negara tersebut. Menurut Direktur Jenderal HKI Departemen kehakiman RI, seperti dikutip di atas, sulitnya pemberantasan pembajakan produk karena kelemahan penegakan hukum. Tetapi kelemahan penegakan hukum barangkali merupakan salah satu variable saja dari maraknya pembajakan. Masih ada banyak variable lain yang juga perlu dipertimbangkan, seperti sosial, budaya dan ekonomi (Lai \& Zaichkowski, 1999).

Pendeknya, memproduksi dan menjual barang bajakan merupakan tindakan kriminal karena melanggar hukum di hampir semua negara 
di dunia (Vagg \& Harris, 2000). Bisnis produk bajakan merupakan bisnis yang sangat jauh dari persaingan bisnis yang adil ketika dikaitkan dengan kompetisi perdagangan. Pabrikan pemegang merek dan paten produk asli harus berkompetisi dengan yang lainnya melalui berbagai strategi marketing dan juga pengeluaran dana yang tidak sedikit, tetapi pembajak cukup mendompleng keberhasilan para pemegang merek dan paten tersebut dalam membangun image produk mereka. Pembajak juga tidak perlu melakukan investasi yang sangat mahal untuk keperluan kontrol kualitas, material yang berkualitas, riset dan pengembangan, dan pemasaran. Karenanya pembajak mampu menjual produknya jauh lebih murah dibandingkan produk yang asli. Kenyataan di atas menunjukkan juga bahwa pembajak mengabaikan kepentingan konsumen yang berkaitan dengan keselamatan. Hasilnya adalah, pabrikan pemegang merek asli dan pemerintah dirugikan. Bagi pabrikan pemegang merek asli paling tidak akan menurunkan tingkat kepercayaan konsumen dan pemerintah kehilangan pemasukan dari pajak (Lynch, 2002; dan Vithlani, 1998).

Paper ini merupakan kajian literature yang memfokuskan pada kajian pembajakan produk dari sisi penjualan dan antisipasi yang telah dilakukan untuk mengurangi pembajakan. Seperti kita ketahui bahwa memproduksi dan menjual produk bajakan merupakan pelanggaran hukum di hampir semua Negara, karenanya review pada kajian ini menjadi penting sebagai kontribusi keilmuan, terutama ilmu marketing.

\section{PERKEMBANGAN BISNIS PEMBAJAKAN DI DUNIA DAN ASIA}

Konsep 'merek dagang' di dunia bisnis sudah digunakan sejak berabad-abad yang lalu, dan problem pembajakan merek dagang juga sudah setua umur merek dagang itu sendiri. Misalnya, pada jaman Yunani kuno, sekitar tahun 800 sampai tahun 400 sebelum masehi, telah digunakannya merek pada pembuatan produk tembikar. Merek dagang telah digunakan oleh bangsa ini sebagai pembeda pembuat tembikar. Tembikar buatan bangsa Yunani nampaknya merupakan tembikar yang terkenal buatannya. Walaupun belum ditemukan bukti tertulis, para ahli percaya bahwa upaya hukum terhadap tindakan kriminal pembajak pada jaman tersebut juga telah dilakukan. Tindakan terhadap pembajak secara tertulis baru ditemukan pada awal abad ke empat belas. Ketika itu hukuman terhadap pembajak sangat keras, bahkan digolongkan sebagai tindakan barbar. Misalnya penguasa lokal mengeluarkan aturan akan menggantung semua pedagang yang ketahuan memproduksi minuman anggur dengan merek 'Rudesheimer' (Jennings, 1989).

Apa yang berubah dengan bisnis pembajakan saat ini adalah karena problem pembajakan sudah menjadi skala global, dan dampaknya 
pada kemerosotan kesejahteraan ekonomi dan keselamatan konsumen di banyak Negara (Lynch, 2002). Daya tarik bisnis pembajakan sudah sangat jelas untuk pelaku pembajakan, misalnya menjanjikan keuntungan yang besar tanpa jerih payah, bebas pajak karena bisnis mereka bersifat illegal, tidak perlu mengeluarkan biaya overhead produksi yang berlebihan, dan jauh kecil resiko hukumnya dibandingkan dengan perdagangan obat bius (Alcock, 2003). Secara detail alasan melakukan pembajakan produk dapat dilihat di dalam Tabel 1.

Tabel 1. Alasan Melakukan Pembajakan Produk

\begin{tabular}{|l|l|}
\hline \multicolumn{1}{|c|}{ Alasan Membajak } & \multicolumn{1}{c|}{ Sumber } \\
\hline $\begin{array}{l}\text { Harga dapat dijual jauh lebih murah dibandingkan aslinya se- } \\
\text { hingga dapat menghasilkan keuntungan yang sangat menjanji- } \\
\text { kan bagi para pembajak }\end{array}$ & $\begin{array}{l}\text { Zaichkowsky \& Simpson, 1996; Dodd \& } \\
\text { Zaichkowsky, 1999; Bush, Bloch, \& } \\
\text { Dawson, 1989; Delener, 2000; Nill \& } \\
\text { Shultz II, 1996; Lynch, 2002; Wijk, 2002. }\end{array}$ \\
\hline $\begin{array}{l}\text { Dampak penyebaran dan perkembangan teknologi yang sangat } \\
\text { pesat di dunia sehingga bisa diakses oleh semua lapisan } \\
\text { masyarakat telah memberikan inspirasi kepada pembajak untuk } \\
\text { melakukan produksi massal produk bajakan yang dapat dibuat } \\
\text { sangat identik dengan produk aslinya. }\end{array}$ & $\begin{array}{l}\text { Nill \& Shultz II, 1996; Bush, Bloch \& } \\
\text { Sawson, 1989; and Bamossy \& }\end{array}$ \\
\hline $\begin{array}{l}\text { Resiko bisnis sangat rendah karena menjanjikan biaya produksi } \\
\text { dan overhead yang sangat murah, jauh lebih murah dibanding- }\end{array}$ & Nill \& Shultz II, 1996; and Delener, 2000 \\
kan proporsi biaya produksi yang dikeluarkan oleh produk asli \\
$\begin{array}{l}\text { karena bahan baku seringkali berkualitas tidak standard, biaya } \\
\text { investasi kecil; dan tidak perlu mengeluarkan biaya riset dan } \\
\text { pengembangan. }\end{array}$ & \\
\hline $\begin{array}{l}\text { Memiliki pasar potensial yang sangat besar karena besarnya } \\
\text { proporsi konsumen dengan penghasilan menengah ke bawah } \\
\text { yang tidak terjangkau membeli produk aslinya. Disamping itu, } \\
\text { infrastruktur hukum yang masih lemah juga menjadi bagian daya } \\
\text { tarik melakukan pembajakan produk. }\end{array}$ & $\begin{array}{l}\text { Bush, Bloch \& Dawson, 1989; Delener, } \\
\text { 2000; Wilkie \& Zaichkowsky, 1999; and } \\
\text { Memproduksi produk bajakan karena sulit berkomoetisi dengan } 2002 .\end{array}$ \\
$\begin{array}{l}\text { produk-produk yang telah begitu kuat dan popular di mata kon- } \\
\text { sumen, sehingga dengan melakukan pembajakan akan mem- } \\
\text { permudah memasarkannya karena mendompleng popularitas } \\
\text { produk aslinya. }\end{array}$ & Nill \& Shultz II, 1996 \\
\hline
\end{tabular}

Namun demikian, pembajak tidak pernah berpikir terhadap pihakpihak yang dirugikan, baik konsumen, pemilik merek asli, dan Negara. Pembajak merugikan kepentingan bisnis, karena merusak reputasi dan membahayakan konsumen yang membeli produk yang tidak memenuhi standard produksi (Green and Smith, 2002). Banyak kaum ibu-ibu di Afrika telah gagal mengatur tingkat kelahiran akibat menggunakan pil KB bajakan/palsu (Grossman and Shapiro, 1988), dan beberapa kecelakaan pesawat domestik yang terjadi di USA karena kesalahan penggunaan suku 
cadang bajakan yang diproduksi dari Negara lain (Jackson, 1994). Diperkirakan suku cadang bajakan yang beredar di USA sebesar $10 \%$ dari total penjualan (Vithlani, 1998). Produk-produk yang di bajak saat ini bukan saja produk-produk mewah, tetapi juga produk-produk konfinien untuk keperluan sehari-hari tidak lepas dari resiko pembajakan (Alcock et al., 2003). ${ }^{1}$

Bisnis produk bajakan sudah menjadi industri yang berkembang dengan sangat pesat saat ini, bahkan industri paling cepat pertumbuhannya di dunia (Alcock et al., 2003). Jika menghitung kerugian financial akibat industri ini, sangatlah sulit memprediksikan karena bisnis ini merupakan bisnis yang tidak tercatat secara jelas berapa jumlah yang dijual maupun berapa keuntungan yang diperoleh, karenanya data bisnis pembajakan amat sangat jarang tersedia (Callan, 1998). Kalaupun ada data, hanya merupakan data yang menggambarkan secara kasar. Misalnya, kerugian pertahun perusahaan pemegang produk asli di USA pertahun sekitar 200 juta dollar US, dan kerugian perusahaan pemegang produk asli di dunia pertahun diperkirakan $5 \mathrm{~s} / \mathrm{d} 10 \%$ dari total perdagangan dunia (Green \& Smith, 2002; and Jayakar, 2003). Perkiraan ini tidak termasuk pembajakan yang terjadi di domestik negara masing-masing. Perkiraan perdagangan dunia pertahun saat ini sekitar 10 triliun dollar US (Green \& Smith, 2002).

Mengutip dari berbagai sumber assosiasi, organisasi dan berita cetak, Vithlani (1998) membuat perkiraan pangsa pasar produk bajakan untuk beberapa sektor produk di dunia (lihat Tabel 2). ${ }^{2}$

\footnotetext{
1 Produk merek terkenal dunia yang dibajak dapat dicontohkan sbb: jam tangan: Cartier, Rolex, Bulgari; tas tangan: Prada, Gucci, Louis Vuitton, Channel; sepatu: Timberland; kacamata: Ray Ban, Armani; Blue jeans: Versace, Armani, and Lacoste (Benghozi \& Santagata 2000). Produk kebutuhan sehari hari yang dibajak misalnya pasta gigi, sampo, kondom, dan sarang burung kalengan (McDonald and Roberts 1994).

2 Maskus (1993) dengan hasil kajiannya telah memetakan kelompok produk yang memiliki potensial problem terhadap persoalan copyright, dan trademark di perdagangan internasional. Kelompok produk yang disebutkan di bawah ini berdasarkan SITC (the Standard International Trade Classification): sebagai berikut:

\begin{tabular}{|c|c|l|}
\hline No & SITC Code & \multicolumn{1}{|c|}{ Description } \\
\hline 1 & 8921 & Copyright-related \\
& 8983 & Printed books, newspaper, periodical \\
& Sound and audio visual recordings, tapes, disks \\
\hline 2 & 112 & Trademark-related \\
& 553 & Alcoholic beverages \\
& 665 & Perfumery, cosmetics, etc. \\
& 784 & Glassware \\
& 821 & Motor Vehicle parts and assesories \\
& 831 & Furniture and parts thereof \\
& 84 & Travel goods, handbags \\
& 8851 & Clothing \\
& 8942 & Watches, movement and cases \\
\hline
\end{tabular}
}


Tabel 2. Pangsa pasar produk bajakan tiap sektor produk di dunia

\begin{tabular}{|c|l|c|}
\hline No. & \multicolumn{1}{|c|}{ Sector } & $\begin{array}{c}\text { Share of counterfeit goods as a percentage of } \\
\text { turnover }\end{array}$ \\
\hline 1 & Watches & 5 \\
\hline 2 & Medicine & 6 \\
\hline 3 & Perfumes & 5 \\
\hline 4 & Aircraft Spare parts & 10 \\
\hline 5 & Toys & 12 \\
\hline 6 & Music & 33 \\
\hline 7 & Video & 50 \\
\hline 8 & Software & 43 \\
\hline
\end{tabular}

Source: Vithlani (1998), published on the responsibility the Secretary General of the OECD

Melihat Tabel 2 tersebut, produk-produk yang berkaitan dengan perangkat lunak komputer dan produk hiburan memiliki pangsa pasar terbesar. Produk-produk ini merupakan hasil rekayasa teknologi yang berkembang sangat cepat, dan dengan pasar sangat besar. Bagi pembajak, memproduksi duplikat perangkat lunak dan produk hiburan (mis: CD musik) tidak merupakan sesuatu yang sulit, karena teknologi sudah bukan merupakan monopoli kelompok tertentu tetapi sudah menyebar ke berbagai lapisan masyarakat. Paling tidak, saat ini tidak ada produk-produk popular seperti perangkat lunak komputer lepas dari resiko pembajakan (Johnson, 2001/2002)

Pesatnya bisnis bajakan ini, menurut berbagai penelitian karena kemampuan pembajak memberikan harga yang sangat murah, jauh di bawah harga produk aslinya (misalnya produk bajakan yang dipasarkan di USA, seperti nampak di Tabel 3), permintaan menjadi sangat besar, dan tentu saja laba yang diraup pembajak berlipat ganda (Ang et al., 2001). Di sisi lain, tindakan pembajak yang semakin merajalela memberikan dampak yang sangat serius terhadap kepercayaan dan keselamatan konsumen serta mengancam perekonomian nasional, berkaitan kemampuan pemerintah menyediakan lapangan kerja, meningkatkan investasi dan penerimaan pajak (Cakraborty, Alfred \& Bristol, 1996; Bloch, Bush \& Campbell, 1993). Mengapa demikian? Konsumen yang dikecewakan karena mengkonsumsi produk bajakan akan berdampak pada menurunnya tingkat kepercayaan mereka kepada pabrikan pemilik produk asli. Akibatnya, penjualan serta keuntungan pabrikan produk asli terancam menurun, investasi menjadi lesu dan akhirnya penyediaan lapangan kerja semakin lemah (Lynch, 2002). 
Tabel 3.

Perbandingan harga produk asli dan produk bajakn di pasar USA

\begin{tabular}{|c|l|c|c|}
\hline No & \multicolumn{1}{|c|}{ Type of product } & Genuine Price & Counterfeit price \\
\hline 1 & Rolex watch & $\$ 4,000$ & $\$ 15-\$ 35$ \\
\hline 2 & Louis Vuitton handbag & $\$ 400$ & $\$ 30-\$ 60$ \\
\hline 3 & Chanel scarf & $\$ 300$ & $\$ 10$ \\
\hline 4 & Ray Ban sunglasses & $\$ 70-\$ 200$ & $\$ 6$ \\
\hline 5 & Gues jeans & $\$ 60$ & $\$ 25$ \\
\hline 6 & Polo Ralp Lauren shirt & $\$ 50$ & $\$ 25$ \\
\hline
\end{tabular}

Source: Caudhry and Walsh (1996)

Tabel 4. Daerah rawan pembajakan produk

\begin{tabular}{|l|l|c|}
\hline No & \multicolumn{1}{|c|}{ Region } & $\begin{array}{c}\text { Percentage of Mentions as a } \\
\text { source of counterfeits }\end{array}$ \\
\hline 1 & Asia*3 & $66 \%$ \\
\hline 2 & Europe & $7 \%$ \\
\hline 3 & Africa & $1 \%$ \\
\hline 4 & Latin America & $7 \%$ \\
\hline 5 & North America & $19 \%$ \\
\hline & & \\
\hline
\end{tabular}

Source: Bush et al. (1989); * without China Mainland

USA mengindentifikasikan beberapa negara yang memiliki reputasi buruk terhadap produk bajakan: Taiwan, South Korea, Hong Kong, Singapore, Thailand, Philippines, Indonesia, Brazil, Colombia, Mexico, and Nigeria. Beberapa dari Negara-negara tertuduh diindentifikasikan menggunakan industri produk bajakan secara de facto menjadi strategi pembangunan industri nasional (Jennings, 1989). Kurun waktu dua dasa warsa ini, Cina sebenarnya juga dibelit oleh masalah produk bajakan. Hampir setiap produk yang memiliki reputasi baik di pasar tidak lepas oleh pembajak (Johnson, 2001/2002; and Choi, 2003).

Asia nampaknya menjadi tertuduh utama pelaku pembajakan produk, dan menjadi perhatian yang sangat serius dari pemerintah USA karena beberapa alasan. Pertama, beberapa Negara Asia menunjukkan perkembangan pasar yang semakin kuat, seperti China, India, Indonesia, and South Korea (World Bank 1995), dimana populasi dan kemampuan belinya meningkat dengan cepat untuk produk yang dilindungi HKI, dan beberapa dari negara itu telah menjadi pesaing bagi perusahaan dari USA dalam pengembangan sektor produk yang syarat dengan teknologi, seperti

3 Pada tahun 2003, Petugas imigrasi USA telah mencatat $66 \%$ total produk bajakan yang masuk ke USA berasal dari Cina. Pemilik merek memperkirakan 15\% s/d 20\% produk merek terkenal yang dipasarkan di Cina adalah produk bajakan. Perkiraan kerugian pemegang merek asli mencapai puluhan juta dolar US per tahun (Chow 2004). 
Video Cam, Camera, telephon seluler, dan Laptop. Kedua, Pasar Asia juga menjadi tempat suburnya para pembajak memasarkan produknya (Callan, 1998). Dengan kata lain, Asia dianggap sebagai sarang pembuatan dan pemasaran produk pelanggar HKI terburuk di dunia (Pendegrast et al., 2002). Tabel 4 di atas merupakan hasil studi dari Bush et al. (1989) yang mengidentifikasikan daerah yang rawan pembajakan menurut pemilik produk asli sebagai responden dalam penelitian ini dan telah menjadi korban pembajakan.

Namun demikian, meskipun menjadi Negara tertuduh yang serius, beberapa Negara seperti China, Singapore, Taiwan sudah sejak lama menerapkan sangsi yang keras terhadap pembajak (Globerman, 1988). Misalnya Cina, Negara ini telah meregister the Quality Brand Protection Committee (QBPC) di bawah the China Association of Enterprises with Foreign Investment yang berkaitan dengan issu-issu anti-counterfeiting. ${ }^{4}$ Indonesia melalui Direktorat Jenderal HKI departemen Kehakiman RI bekerjasama dengan PT. Microsoft Indonesia juga menunjukkan keseriusan memberantas produk bajakan, yaitu dengan mengembangkan cetak biru sistem komputerisasi yang akan dipakai di lingkungan Direktorat Jenderal HAKI. Cetak biru tersebut mencakup proses registrasi paten, merek, atau hak cipta secara online, dan sarana komunikasi internal dengan seluruh kantor wilayah di seluruh Indonesia (KCM, 2005). ${ }^{5}$

Namun demikian, satu problem yang muncul di negara-negara subur pembajakan adalah tidak memilikinya kesatuan kebijakan instansi terkait, sehingga menghadapi kesulitan menegakkan hukum/peraturan yang telah di buat sebagai penangkal penyalahgunaan HKI (Johnson, 2001/2002), seperti juga yang dikatakan oleh Dirjen HKI Departemen Kehakiman RI Indonesia di atas.

\footnotetext{
${ }^{4}$ The Quality Brands Protection Committee (QBPC) didirikan oleh kelompok pemilik merek asli terkenal pada tahun 2000. Tujuan QBPC adalah memeberikan informasi dan data kepada pemerintah tentang issu-issu yang berkaitan dengan proteksi merek dagang, dan berupaya memeberikan masukan untuk perubahan peraturan, serta memberikan pendidikan kepada masyarakat China tentang HKI (Managing Intellectual Property 2003, p.1).

5 Kerjasma upaya pemberantasan pembajakan produk juga dilakukan antara Direktorat Jenderal HKI dengan Business Software Alliance (BSA), Asosiasi Perangkat Lunak Indonesia (Aspiluki), Asosiasi Pengusaha Komputer Indonesia (Apkomindo), dan Karya Cipta Indonesia (KCl). Operasi bersama dengan aparat Polri sudah jauh hari dilakukan sebagai bagian nota kesepahaman antara Ditjen HAKI dengan Kepolisian Republik Indonesia. Sejak diberlakukannnya UU HKI Nomor 19 tahun 2002, kerugian akibat penggunaan software ilegal di Indonesia turun dari 89 persen menjadi 87 persen tahun 2004. Penurunan yang sangat kecil sekali ini selama dua tahun pemberlakuan UU HKI menunjukkan bahwa pemerintah RI masih memerlukan upaya dan kerja keras mencari strategistrategi jitu selain kerjasama yang dilakukan di atas. Menurut laporan tahunan BSA/IDC Global Software, Indonesia masih menempati urutan kelima tertinggi di dunia untuk pembajakan software setelah Vietnam, China, Ukraina, dan Zimbabwe (KCM 2005).
} 
Meskipun upaya penangkalan pelanggaran HKI telah dilakukan oleh negara masing masing maupun dengan cara kerjasama bilateral antar negara, bahkan melalui organisasi perdagangan dunia atau World Trade Organisation (WTO), menjamurnya bisnis pembajakan di Asia masih jauh dari harapan pemilik/pemegang merek asli, dan belum bisa diredam atau dikurangi secara signifikan. Jacobs et al. (2001) memberikan alasan bahwa banyak negara Asia mengalami proses industraliasasi masih dalam hitungan umur yang sangat muda. Karenanya negara-negara tersebut masih belum memiliki format infrastruktur hukum yang jelas dalam mendukung keberadaan $\mathrm{HKI}$, sehingga penegakan hukum juga masih belum konsisten. Demikian juga perlu diperhitungkan bahwa kebanyakan masyarakat bisnis Asia memiliki jiwa kewiraswastaan secara alamiah dan tidak ada kendala moral yang menahan penggunaan atribut orang lain untuk digunakan kepentingan sendiri (Harvey \& Ronkainen 1985). Kenyataan ini nampaknya juga didukung oleh budaya Asia yang mendahulukan kepentingan bersama daripada kepentingan individual. HKI dianggap sebagai kental dengan pengaruh budaya barat karena membela kepentingan individual di atas kepentingan bersama (Swinyard et al., 1990). ${ }^{6}$

\footnotetext{
${ }_{6}^{6}$ Pengertian hak milik telah mengalami perdebatan yang panjang di dunia Barat, sejak jaman Plato sampai dengan abad modern ini. Tokoh-tokohnya dapat kita sebut misalnya John Locke, JeanJacques Rousseaw, Jeremy Benthan, Karl Marx, John Stuart Mill, Thomas Hill Green, Thorstein Veblen, R.H. Tawney, Morris Cohen, Charles A. Reich, dan C.B. Macpherson. Pengertian milik tidak pernah tetap dari waktu ke waktu, bahkan cenderung ke kontroversial karena masalahnya tidak hanya berupa apakah seharusnya pranata milik itu, tetapi juga perdebatan mengenai hakekat pranata milik itu. Begitu masyarakat memiliki harapan yang berlainan, maka mereka akan melihat fakta-fakta tentang pranata kepemilikan berbeda pula. Fakta-fakta mengenai pranata buatan manusia yang menciptakan dan melestarikan hubungan-hubungan tertentu antara orang-orang, dan itulah sesungguhnya hakekat milik itu, tidak pernah sederhana karena pranata kepemilikan dibuat dan dipertahankan dengan tujuan tertentu yang dianggap esensial. Pengertian kata 'milik' di dalam masyarakat secara umum adalah 'harta benda'. Tetapi dalam penegrtian ahli pilosopi, ahli hukum, dan ahli-ahli teori sosial dan politik mneyebutkan bahwa 'milik' bukanlah 'harta benda' melainkan 'hak', hak atas harta benda. Suatu hak dalam arti suatu klaim yang dapat dipaksakan atas kegunaan dan manfaat suatu benda oleh negara, hukum dan adat. Disamping itu, menurut John Locke menyebutkan bahwa dunia dan isinya adalah pemberian Tuhan untuk manusia, namun pemberianTuhan ini dapat di klaim menjadi hak milik manusia secara pribadi atau kelompok kalau sudah melibatkan kreatifitas manusia itu sendiri (Macpherson 1978). Dari pemahaman di atas, nampaknya konsep HKI tidak lepas dari pengertian milik sebagai hak yang dikaitkan dengan hak atas intelektual, intelektual adalah pemberian Tuhan, tetapi hasil kreatifitas intelektual merupakan klaim sebagai hak pribadi atau kelompok yang dapat dipaksakan atas kegunaan dan kemanfaatannya.

Secara historis, kesepakatan HKI di secara internasional yang dimotori dunia barat sudah lebih dari seratus tahun yang lalu, dan kesepakatan akan dilakukan sesuai dengan perkembangan jaman. Kesepakatan yang telah dilakukan sbb:

\begin{tabular}{|c|l|l|l|}
\hline No. & \multicolumn{1}{|c|}{ Kesepakatan } & \multicolumn{1}{c|}{ Hasil Kesepakatan } & Tahun \\
\hline 1 & Paris Convention & Kekayaan industri yang menyangkut paten, trademark dan desain & 1883 \\
\hline 2 & Berne Convention & Kekayaan menyangkut copyrights & 1886 \\
\hline 3 & Rome Convention & Kekayaan yang menyangkut rekaman berkaitan dengan kesenian, misal musik. & 1961 \\
\hline 4 & The Budapest Treaty & $\begin{array}{l}\text { Kekayaan yang menyangkut deposit atas mikro organisme untuk tujuan } \\
\text { prosedur paten }\end{array}$ & 1977 \\
\hline 5 & Washington Treaty & Kekayaan yang menyangkut desain untuk layout sirkuit yang terintegrasi & 1989 \\
\hline
\end{tabular}
}


McDonald \& Roberts (1994) juga menyebutkan bahwa pelanggaran HKI subur di Asia karena adanya perbedaan budaya dalam memahami aspek moralitas dan cara pandang memahami nilai-nilai hidup antara Barat dan Timur. Dikaitkan dengan HKI, Barat dan Timur berbeda pandang dalam konsep kepemilikan (Mittelstaedt \& Mittelstaedt, 1997). Budaya Asian secara tradisional menekankan kepada mendahulukan kepentingan bersama, dan individu memiliki kewajiban memberikan kemampuannya untuk kepentingan masyarakat (Lai \& Zaichkowsky, 1999). Dengan demikian, ide-ide baru atau temuan-temuan baru selalu dianggap dapat diakses atau dimanfaatkan oleh semua orang secara komersial (Jacobs et al., 2001). ${ }^{7}$

Sebaliknya, HKI merefleksikan nilai-nilai 'Bangsa Barat' pada umumnya. Banyak orang Asia melihat HKI sebagai upaya bangsa barat untuk mempertahankan monopoli perdagangan mulai dari teknologinya, produksi produknya dan memasarkan produk tersebut (Altbach 1988; and Swinyard et al., 1990). Deng et al. (1996) menambahkan bahwa produkproduk yang dilindungi HKI hanya akan meningkatkan harga yang lebih tinggi, karenannya ketika tekanan dari pihak pemerintah 'Barat" kepada pemerintah 'Timur', seperti misalnya Cina, supaya membuat hukum-hukum yang yang memberi pelanggaran $\mathrm{HKI}$, pembuatan produk bajakan di Cina tidak kunjung surut jumlahnya. Kenyataan dilapangan, hukum atau peraturan untuk melindungi HKI di buat sedemikian rupa, pembajak tetap saja

\begin{tabular}{|c|l|l|c|}
\hline 6 & $\begin{array}{l}\text { Uruguay Round of } \\
\text { Multilateral Trade } \\
\text { Negotiations }\end{array}$ & $\begin{array}{l}\text { Salah satu kesepakatannya adalah kesepakatan yang menyangkut } \\
\text { perdagangan yang berkaitan dengan HKI* }\end{array}$ & 1995 \\
\hline
\end{tabular}

Sumber: Revest 1999; * Indonesia harus melakukan HKI sesuai dengan kesepakatan di Uruguay Round paling lambat 1 Januari 2000.

7 Wilkie \& Zaichkowsky (1999) mengatakan bahwa budaya mengkopi atau meniru merupakan budaya yang sudah lama di Asia dan dapat dilihat dari sejarah dan sistem nilainya yang direflesikan ke dalam system hukumnya. Metode tradisional pendidikannya juga mengajarkan bagimana mengkopi sesuatu, meniru sesuatu yang dianggap bagus mlsalnya menulis halus, meniru huruf kanji yang artistic. Budaya Asia juga sangat mengutamakan keluarga dan setiap anggota keluarga saling membenatu untuk kepentingan keutuhan bersama. Negara tidak memberikan manfaat secara langsung terhadap kebutuhan keluarga sehingga tidak menjadi prioritas perhatian. Itulah sebabnya barangkali tidak adanya hukum yang efektif untuk mencegah pengambilan keuntungan oleh wiraswastawan alamiah Asia dari perusahaan-perusahaan besar pemegang HKI, apalagi yang berasal dari luar Asia.

Bangsa Asia yang terkenal dengan kepercayaan spiritualitasnya yang kuat, keberadaan nilai-nilai konghucu dan Islam memberikan pengaruh yang signifikan karena pemeluknya lebih dari lima puluh persen populasi Asia. Konghucu dan Islam memandang bahwa konsep meniru bukan sesuatu tindakan yang memalukan atau tindakan yang rendah. Dan melanggar hukum. Islam sendiri memiki argumentasi bahwa segala sesuatu berasal dari Tuhan (Mandhachitara et al. 2000). Pandangan demikian akan menurunkan semangat para penemu untuk tetap berprestasi (Mittelstaedt \& Mittelstaedt 1997). Namun demikian, peran HKI di komunitas Islam sendiri sebenarnya masih dalam proses debat public. Dalam kasus ini, misalnya muslim Indonesia. Masih ada perbedaan cara pandang dalam melihat peranan HKI di dalam hukum Islam. Majelis Ulama Indonesia (MUI) dengan mengacu pada berbagai sumber literature memandang bahwa HKI dilindungi oleh syariah Islam. Tetapi Jamaah Murabitun Nusantara tidak setuju dengan pendapat MUI ini karena mereka berpendapat alam dan isinya milik Allah SWT, termasuk manusia dan ilmu yang ada di dunia ini karena itu HKI bisa diabaikan peranannya ( www.Hukumonline.com 2003). 
mampu mensiasati hukum atau peraturan tersebut. Semakin ketat hukumnya, semakin canggih para pembajak melindungi bisnisnya (Birden, 1996; and Wilkie \& Zaichkowsky, 1999). Oleh karena itu, tidaklah mengherankan jika Negara-negara Asia menjadi daerah subur pembajakan baik dari proses produksi sampai dengan memasarkannya, dan kondisi ini mendorong para ahli pemasaran di Asia memperhitungkan dengan serius problem produk bajakan ini (Chan, Wong \& Leung, 1998).

\section{JENIS KONSUMEN PEMBELI PRODUK BAJAKAN}

Ada dua tipe konsumen dari produk bajakan: konsumen yang tertipu dan konsumen yang sadar membeli produk tersebut. Pertama, konsumen yang tertipu. Mereka ingin membeli produk asli tetapi tidak sadar kalau yang dibeli produk palsu (Chakraborty et al., 1996). Dalam kasus ini, informnasi pasar tentang produk tersebut tidak sempurna atau ada informasi yang disembunyikan kepada konsumen (Grossman \& Shapiro, 1988). Hasilnya adalah konsumen menjadi korban penipuan.

Kedua, konsumen sadar membeli. Mereka dengan sadar sengaja membeli produk bajakan termasuk di dalamnya tingkat harga dan kualitas yang ditawarkan. Mereka sadar bahwa ketersediaan produk tersebut hanya ada di pasar gelap (Chakraborty et al., 1996). Biasanya harga produk yang murah merupakan alasan konsumen yang sadar membeli produk bajakan, dan mereka sadar dengan tingkat resiko mengkonsumsi produk yang dibeli. Misalnya, konsumen akan cenderung membeli baju bermerek dibandingkan membeli suku cadang mobil atau obat-obatan bajakan karena alasan resiko (Delener, 2000). Dalam kasus ini, munculnya pembeli produk bajakan secara sadar, karena pihak pabrikan atau pemilik produk asli dianggap gagal menyediakan produknya dengan harga yang terjangkau oleh sebagian konsumen (Lai \& Zaichkowsky, 1999).

\section{MACAM STRATEGI MASUK BISNIS PRODUK BAJAKAN}

Ada dua dasar pendekatan untuk masuk ke dalam bisnis pembajakan, pendekatan langsung dan pendekatan tidak langsung, dan strategi ini telah dilakukan oleh pembajak produk yang bergerak secara internasional (Harvey \& Ronkainen, 1985; and Delener, 2000). Setiap pendekatan memiliki dua strategi operasi yang berbeda.

Gambar 1 menunjukkan srategi masuk bisnis pembajakan secara langsung (1) dari sebuah perusahaan atau individual yang berkeinginan melakukan tindakan pembajakan. Pembajak membeli produk aslinya untuk dipelajari dan diproduksi secara massal di negara ketiga. Produk yang sudah jadi kemudian di import ke negara pembajak untuk dipasarkan. Alasan memproduksi di negara ketiga untuk mengurangi aspek legalitas. 
Gambar 1: Pembajakan langsung (1)

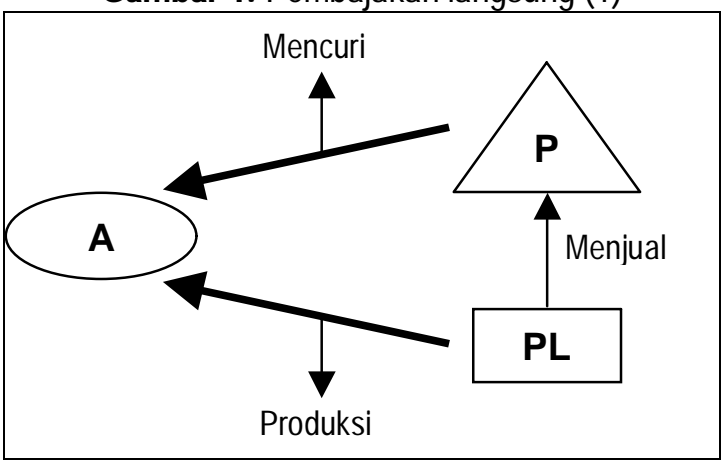

Keterangan:

$\mathrm{A} \quad=$ Asal negara pemegang $\mathrm{HKI}$

$\mathrm{P} \quad=$ Pembajak

$\mathrm{PL} \quad=$ Pasar Luar Negeri

$\leftarrow=$ Arah kegiatan

Gambar 2: Pembajakan langsung (2)

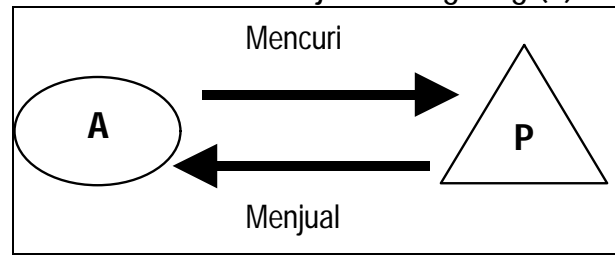

Keterangan:

$\mathrm{A}=$ Asal negara pemegang $\mathrm{HKI}$

$\mathrm{P} \quad=$ Pembajak

$\leftarrow=$ Arah kegiatan

Strategi masuk bisnis pembajakan secara langsung (2) dilakukan dengan membeli formula produk asli dari karyawan perusahaan produk asli yang bersedia di suap. Karyawan yang tahu dengan formula produk (biasanya di bagian proses produksi) mencuri dan diserahkan kepada pembajak dengan imbalan uang. Formula yang diperoleh digunakan untuk bahan produksi secara masal di negara pembajak dan di pasarkan ke negara produk aslinya berasal. Model ini jarang sekali dipublikasikan karena sulit mendeteksi dan membuktikan bagaiamana formula produk aslinya diperjualbelikan, dan biasanya banyak terjadi di perusahaan komputer (Harvey and Ronkainen, 1985). Gambar 2 di atas menunjukkan proses pembajakan langsung (2) tersebut.

Adapun proses strategi masuk bisnis pembajakan secara tidak langsung (1) adalah pembajak menggunakan perantara atau broker yang 
bersedia membantu mencuri formula produk asli. Pembajak membuat perjanjian kontrak dengan perantara atau broker untuk mendapatkan formula produk asli. Berdasarkan formula yang diperoleh digunakan untuk memproduuksi secara masal di negara pembajak dan dipasarkan ke Negara lain. Alasannya untuk mengurangi aspek legalitas. Misalkan, bukti produk bajakan banyak sekali tertangkap di pintu masuk pelabuhan import di USA dan produk dari Cina memiliki porsi $66 \%$ dari total produk yang tertangkap (Chow, 2004). Proses tersebut ditunjukkan pada Gambar 3.

Gambar 3: Pembajakan tidak langsung (1)

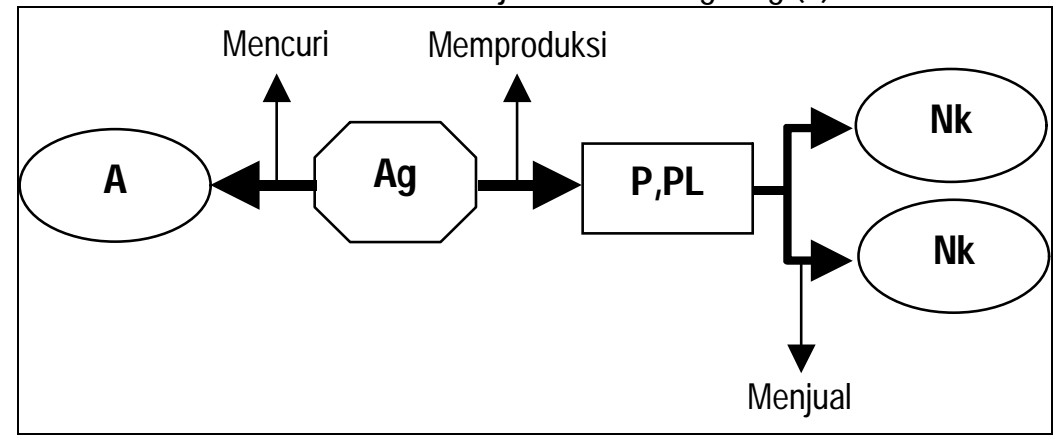

Keterangan:

$\mathrm{A}=$ Asal negara pemegang $\mathrm{HKI}$

$\mathrm{P} \quad=$ Pembajak

$\mathrm{Ag}=$ Agen/penghubung

$\mathrm{PL} \quad=$ Pasar Luar Negeri

$\leftarrow=$ Arah kegiatan

Nk = Pasar produk bajakan di negara ketiga (selain negara pemegang HKI dan negara tempat memproduksi produk bajakan)

Gambar 4: Pembajakan tidak langsung (2)

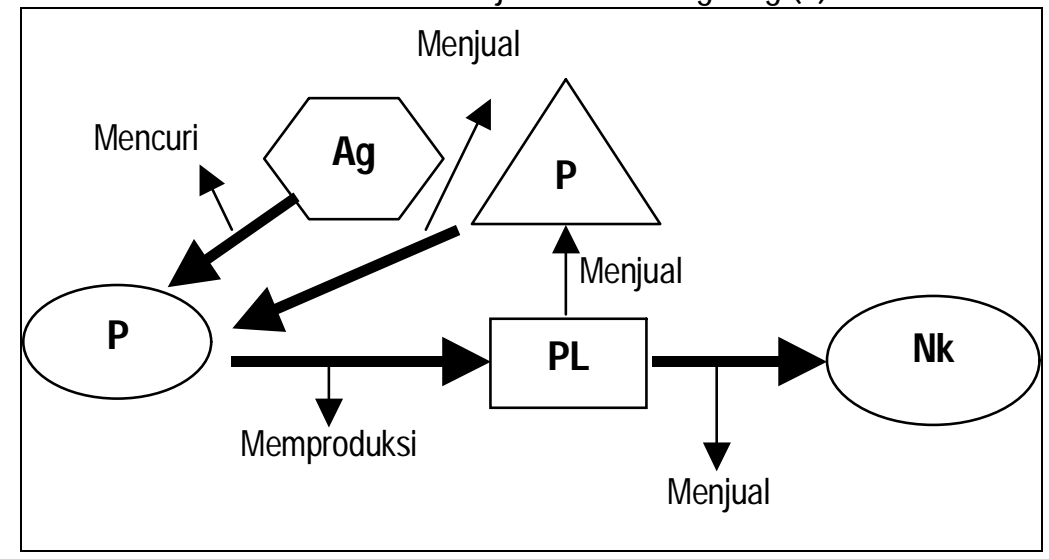


Keterangan:

$\mathrm{A}=$ Asal negara pemegang $\mathrm{HKI}$

$\mathrm{P} \quad=$ Pembajak

$\mathrm{Ag}=$ Agen/penghubung

$\mathrm{PL} \quad=$ Pasar Luar Negeri

$\leftarrow=$ Arah kegiatan

Nk = Pasar produk bajakan di negara ketiga (selain negara pemegang HKI dan negara tempat memproduksi produk bajakan)

Terakhir, Gambar 4 menunjukkan strategi masuk bisnis pembajakan secara tidak langsung (2) dari pembajak yang memanfaatkan jasa perantara atau broker untuk mencuri formula. Dari formula yang diperoleh di gunakan memproduksi secara massal di Negara yang bukan Negara pembajak, dan dipasarkan ke Negara pembajak maupun ke Negara lainnya. Strategi ini biasanya pembajak berada dinegara yang memiliki aspek legalitas yang ketat, misalnya dinegara maju. Negara-negara berkembang menjadi pilihan untuk basis produksi produk mereka. Alasannya adalah selain menghindari aspek legal juga menghindari biaya tenaga kerja yang mahal.

\section{PERKEMBANGAN STRATEGI ANTI-PEMBAJAKAN}

Topik riset dan diskusi pembajakan produk atau pelanggaran HKI telah berkembang di kalangan pakar ilmu ekonomi, hukum, dan ahli pemasaran, dan telah memberikan kontribusi yang cukup baik bagi perkembangan dunia ilmu. Khususnya untuk ilmu pemasaran, penelitian yang dikaitkan dengan pembajakan produk dapat masuk ke bidang perilaku konsumen. Strategi pemasaran, dan pemasaran internasional. ${ }^{8}$ Oleh karena itu, penelitian pembajakan produk di ilmu pemasaran dapat dilakukan dari dua sisi, penelitian pada sisi permintaan dan penelitian pada sisi penawaran. Penelitian pada sisi permintaan masih sedikit jumlahnya. Topik yang dibahas biasanya menyangkut perilaku konsumen yang memiliki dimensi majemuk. Penelitian yang sudah dilakukan oleh para ahli pemasaran masih belum terbangun menjadi kerangka teori yang kuat, sehingga masih banyak peluang bagi peneliti pemasaran untuk melakukan penelitian di bidang ini (Field, 2000). Penelitian yang pernah dilakukan, misalnya penelitiannya Bloch et al. (1993); Bush et al. (1989); Tom et al. (1998), dan Field (2000).

\footnotetext{
8 Lihat penelitian yang telah dilakukan oleh: Olsen \& Granzin 1992; Bloch et al. 1993; Bloch et al. 1993; McDonald \& Roberts 1994; Chaudhry \& Walsh 1995; Cakraborty et al. 1996; Wee et al. 1996; Lai \& Zaichkowsky 1997; Chan et al. 1998; Cordell et al. 1996; Tom et al. 1988; Wilkie \& Zaichkowsky 1999; Miller 1999; Field 2000; Delener 2000; d'Astous \& Gargouri 2001; Dodd \& Zaickhowsky 2000; Phau et. al. 2001; Ang et al. 2001; Lynch 2002; Kwong et al. 2003).
} 
Penelitian pada sisi penawaran seringkali difokuskan pada investigasi strategi pembajakan dan mengindentifikasi strategi-strategi anti pembajakan yang efektif. Tujuan utamanya adalah berupaya mengurangi atau membatasi ruang gerak para pembajak, mengingat suatu hal yang mustahil menghilangkan penyakit pembajakan yang sudah berusia lebih dari seribu tahun ini. Upaya ini akan efektif dengan keterlibatan aktif pemegang HKI (perusahaan pemegang merek asli) dan pemegang power (pemerintah). Upaya memerangi bisnis pembajakan sudah dilakukan dengan berbagai macam jurus atau strategi, dari membawa tertuduh ke meja hijau sampai dengan membangun benteng disetiap distributor untuk tidak terinfeksi oleh upaya penyaluran produk bajakan (Olsen \& Granzin, 1992; and Field, 2000).

Dari hasil review tulisan-tulisan ilmiah di berbagai sumber telah ditemukan berbagai strategi dan taktik yang telah formulasikan oleh para ahli pemasaran. Beberapa bentuk strategi anti pembajakan dan contoh penerapannya dari beberapa literature yang berhasil dikumpulkan sbb: ${ }^{9}$

\section{a. Warning strategy}

Perusahaan pemegang merek asli memberikan peringatan secara aktif kepada para konsumennya terhadap produk perusahaan tersebut yang dipalsukan. Contohnya Pembuat jam tangan terkenal di dunia merek Rolex membuat iklan di the Wall Street Journal yang memberikan pendidikan kepada konsumennya bagaiamana membedakan produk Rolex asli dengan Rolex palsu. Dengan melakukan pendidikan kepada konsumen, maka diharapkan pembelian dan penjualan produk palsu dapat di kurangi karena kesadaran akan bahaya dan kerugian yang ditimbulkan oleh produk palsu tersebut terhadap konsumen dan produsen. Strategi ini dipandang sangat mahal, karena harus di kampanyekan lewat media massa seperti koran atau televisi, tetapi dalam jangka panjang, perusahaan akan mendapatkan profit yang lebih baik.

b. Withdrawal strategy

Perusahaan pemegang merek asli mengawasi dan memilih secara ketat distributor yang memasarkan produknya di pasar yang dicurigai produk bajakan sangat banyak dijual. Produk- produk di bawah merek 'Hunting World' hanya dijual pada 80 pengecer di seluruh dunia. Kasus penjualan kaos merek Dagadu Yogyakarta yang hanya membuka outlet penjualan produknya terbatas, bertujuan untuk memberikan kepastian kepada konsumennya bahwa produk yang dibeli asli.

\footnotetext{
${ }^{9}$ Lihat: Harvey \& Ronkainen (1985), Harvey (1988), Bush, Bloch \& Dawson (1989), Chaudhry \& Walsh (1996), Shultz II \& Saporito (1996), Dodd \& Zaichkowsky (1999), Delener (2000), and Jacobs, Samli \& Jedlik (2001)
} 


\section{c. Prosecution strategy}

Perusahaan pemegang merek asli melibatkan tim penyidik yang dibentuk oleh perusahaan sendiri untuk melakukan penyelidikan secara aktif tempat-tempat yang dicurigai sebgai pembuat produk palsu dari perusahaan tersebut. Contoh perusahaan yang sudah melakukannya, misalnya, Rolex dan Christian Dior. Namun, persoalan di lapangan muncul ketika ada perusahaan yang dicurigai sebagai pembuat produk palsu yang seharusnya dikenai sangsi hukum tetapi karena penegakan hukum diberbagai Negara berbeda, menyebabkan sangsi hukum yang seharusnya dikenakan tersebut tidak terjadi, atau kadang sangsi hukumnya tidak seimbang dengan perbuatan yang dilakukannya.

\section{d. Hands-Off strategy}

Perusahaan pemegang merek asli membiarkan pembajakan produknya karena berbagai alasan. Misalnya, biaya untuk memerangi pemebajakan melalui upaya hukum sangat tinggi dan hasilnya seringkali tidak maksimal. Ukuran pasar yang tidak terlalu besar di suatu Negara untuk produk tertentu sering dipandang tidak siknifikan untuk diperangi karena produk tersebut hanya dipasarkan di domestic, dan kualitasnya sangat rendah sehingga mudah dikenali sebagai produk palsu. Kebijakan ini terutama hanya digunakan untuk negara-negara terbelakang atau mulai masuk ke kategori berkembang yang ingin menikmati produk-produk dengan merek terkenal. Biasanya produk yang disukai oleh mereka dalah produk yang memiliki nilai 'pop culture'. Bisa juga produk-produk yang berdaur hidup sangat pendek dengan harga murah, misalnya software dengan pemakaian jangka waktu tertentu, juga seringkali tidak memerlukan perhatian yang serius terhadap pembajakan produknya, karena pembeli akan memilih produk asli yang harganya terjangkau dan memiliki garansi. Kadang strategi ini dilakukan oleh pemiliknya karena pemilik merek asli khawatir akan kehilangan konsumennya akibat pindah ke produk lainnya, sehingga membiarkan konsumen tidak tahu bahwa produk tersebut sering dipalsukan. Misalnya Gucci yang menggunakan Warning Strategy telah menduga bahwa konsumennya pindah ke produk merek lain yang tidak tersentuh oleh produk palsu. Konsumen yang biasanya membeli dompet 'Gucci' bergeser membeli dompet 'Fendi'.

\section{e. Monitoring Strategy}

Perusahaan pemegang merek asli memandang bahwa distributor adalah pemegang kunci penyebaran produk palsu dipasar. Karena itu, pendekatan dengan distributor untuk membangun loyalitas akan lebih efektif dalam menghentikan produk bajakan di pasar. Distributor di 
dorong untuk memegang peranan aktif dengan cara melaporkan setiap temuan yang mencurigakan terhadap kemungkinan produk palsu. Strategi ini biasanya di ikuti dengan berbagai macam insentif untuk mendorong keaktifan distributor memerangi pembajakan produk. Banyak produk merek terkenal yang bersifat 'luxury' atau mewah dan mahal memiliki hubungan dengan pengecer yang memiliki reputasi tinggi dalam hal penjualan produk asli. Dengan reputasinya ini penjual bahkan berani menanggung denda kerugian kalau produk yang dijualnya ternyata palsu, sehingga mereka sangat aktif membantu memerangi produk bajakan karena pada akhirnya akan merugikan mereka (pengecer). Contohnya adalah Mr. Charles Bogar, seorang pengecer produk mewah di San Farnsisco, berani mengeluarkan uangnya untuk bayar denda sebasar 1,7 juta dollar karena klaim dari pemebelinya bahwa produk yang dijual ada yang palsu (Chaudhry \& Walsh 1996).

f. Modification Strategy

Perusahaan pemegang merek asli melakukan upaya menciptakan metode pelabelan dengan dibantu temuan-temuan teknologi terkini untuk membedakan produk asli dan produk palsu (lihat Tabel 5). Nampaknya upaya ini memberikan harapan yang baik, tetapi tidak berapa lama pelabelan deteksi digunakan, para pembajak juga mampu mengantisipasi deteksi tersebut. Hal ini tidak mengherankan karena penyebaran teknologi canggih sudah semakin mudah dan akses untuk menguasainya semakin terbuka untuk berbagai lapisan dan golongan masyarakat (Chaudhry \& Walls 1996). Misalnya, ketika teknologi hologram digunakan di kartu kredit untuk mengidentifikasi keaslian kartu tersebut, dengan segera para pembajak melakukan upaya peniruannya tanpa menemui banyak kesulitan dengan teknologi yang dikuasai mereka.

g. Consultation

Perusahaan pemegang merek asli melakukan peran aktif bekerjasama dengan lembaga pemerintah maupun dengan pemegang merek asli lainnya. Dengan lembaga pemerintah, dalam kaitannya memberikan masukan dan membangun lobi dengan politikus dan penegak hukum untuk memperkuat penegakan hukum dan pembuatan produk hukum yang berkaitan dengan HKI. Contohnya adalah perusahaan-perusahaan pemegang merek asli yang beroperasi di China membangun The Quality Brands Protection Committee (QBPC) secara aktif memberikan masukan kepada lembaga pemerintahan China yang berkaitan dengan pelaksanaan peraturan HKI. Membangun kerja sama antar pemegang merek asli melalui koalisi anti pembajakan produk. Contohnya adalah the International Anti-Counterfeiting Coalition (IACC). Organisasi ini adalah sebuah lembaga yang berisikan para 
pabrikan produk asli, investigator dan ahli hukum yang berhubungan dengan pembajakan produk. Tujuannya adalah mendorong berjalannya hukum secara efektif baik di hukum domestic negara tertentu maupun hukum internasional. Lembaga ini juga memberikan informasi yang berkelanjutan kepada anggotanya maupun masyarakat melalui internet atau media lainnya.

Tabel 5. Metode Pelabelan untuk Anti Pembajakan

\begin{tabular}{|c|c|c|}
\hline No & Metode & Produk \\
\hline 1 & - Hollogram & $\begin{array}{ll}\text { - } & \text { Direct Card } \\
\text { - } & \text { CD }\end{array}$ \\
\hline 2 & - Hidden Words & $\begin{array}{ll}\text { - } & \text { Check } \\
\text { - } & \text { Student Transkript } \\
\text { - } & \text { Credit Card }\end{array}$ \\
\hline 3 & $\begin{array}{l}\text { - Fluorescant Light } \\
\text { - Invisible } \\
\text { - Safety Paper } \\
\end{array}$ & - $\quad$ Paper Document \\
\hline 4 & - Polaproof & - $\quad$ Packaging label \\
\hline 5 & - DNA Security Maker & $\begin{array}{ll}\text { - } & \text { Passport } \\
\text { - } & \text { Currency } \\
\text { - } & \text { CD } \\
\text { - } & \text { Software packages } \\
\text { - } & \text { Pens } \\
\text { - } & \text { Telephone card } \\
\end{array}$ \\
\hline 6 & $\begin{array}{l}\text { - Sigma Three Secure } \\
\text { - Document System }\end{array}$ & - $\quad$ Paper document \\
\hline 7 & - PIN Number & $\begin{array}{ll}\text { - } & \text { Credit card } \\
\text { - } & \text { ATM card } \\
\text { - } & \text { Telephone card } \\
\end{array}$ \\
\hline 8 * & $\begin{array}{l}\text { - Watermarks } \\
\text { - Color }\end{array}$ & $\begin{array}{ll}\text { - } & \text { Paper documents } \\
\text { - } & \text { Paper documents } \\
\end{array}$ \\
\hline
\end{tabular}

Sumber: Delener 2000; * Chaudhry \& Walls 1996

h. Awareness, Action and Assertion

Harvey (1987) memberikan alternatif strategi yang lebih komprehensif karena dipandang lebih memberikan hasil lebih baik dengan melalui tiga langkah strategi yang dilakukan dalam satu kesatuan, yaitu meningkatkan 'awareness', mengembangkan 'action' plan, and melakukan 'assertion' atas hak perusahaan untuk memerangi pembajakan produk. Langkah pertama adalah memberikan kesadaran kepada semua pelaku bisnis yang terlibat dalam produk yang dijual, baik itu konsumennya, distributornya maupun pelaksana penegak hukumnya, melalui berbagai lobi, media dan publikasi. Misalnya perusahaan 
memberikan daftar distributor dan pengecer yang di beri hak penjualan produknya secara resmi kepada konsumen melalui iklan. Disamping itu, perusahaan sebaiknya juga menjadi anggota aktif di berbagai asosiasi anti pembajakan produk, misalnya IACC (International Anti Counterfeiting Coalition). Dengan bergabungnya perusahaan pemilik merek asli diberbagai asosiasi baik internasional maupun domestik diharapkan tindakan memerangi pembajakan lebih memberikan hasil yang nyata. Indikator yang dapat disebut 'hasil nyata' tersebut, misalnya perusahaan dapat mempertahankan atau meningkatkan kemampuan menghasilkan laba pertahun, perusahaan mampu meningkatkan nilai perusahaan melalui harga saham yang kuat, dan kemampuan membayar pajak ke pemerintah juga semakin besar.

Langkah selanjutnya adalah melaksanakan tindakan nyata dalam upaya meningkatkan 'awareness' melalui semua staf perusahaan dari tingkat atas sampai ke bawah, terutama salah satu manajer diberi kekuasaan untuk selalu berkomunikasi dengan media massa tentang segala aktifitas dan kerugian yang ditimbulkan oleh pembajakan produk. Demikian juga, perusahaan di dorong aktif terlibat di asosiasi anti pembajakan dengan memperjuangkan plan yang sudah digariskan oleh perusahaan. Harvey (1987) menyarankan perusahaan membuat divisi khusus untuk menangani berbagai masalah yang menyangkut pembajakan produk.

Langkah terakhir adalah melakukan 'assertion' strategi dengan melakukan kampanye atau pernyataan aktif kepada pemerintah melalui berbagai lobi-lobi yang dilakukan oleh chairman perusahaan dalam rangka mempengaruhi pembuatan peraturan dan hukum yang lebih tegas dan kuat. Perusahaan yang melakukan strategi ini adalah Microsoft dengan produknya yang menyebar ke seluruh dunia dan sangat popular bagi pembajak karena sangat mudah ditiru dan sangat menguntungkan. Microsoft menggarap secara serius pasar China karena jumlah pemakai produknya sangat banyak. Untuk memperkecil ruang gerak pembajak, Microsoft bekerja sama dengan pemerintah China mengembangkan Windows versi China sehingga sangat mudah digunakan oleh masyarakat China karena semua perintah dalam program menggunakan bahasa China.

Perusahaan-perusahaan berskala internasional terutama yang sangat syarat dengan Hak Kekayaan Intelektual seperti Microsoft atau Rolex telah secara aktif melakukan berbagai cara memerangi pembajakan. Biaya yang dikeluarkan sudah dalam hitungan jutaan dollar. Namun, kenyataan di lapangan, dari berbagai strategi anti pembajakan yang telah di implementasikan di pasar, nampaknya upaya para operator bisnis pemegang HKI dan pemerintah belum menunjukkan hasil yang memuaskan 
dalam memerangi pembajak. Penyebabnya mungkin bisa berbagai macam, tetapi dari hasil sementara penelitian yang telah ada adalah karena konflik budaya dan penafsiran HKI, serta penegakan hukum yang belum maksimal. Namun demikian, penelitian yang dilakukan oleh Bamossy \& Scammon 1984 menemukan bahwa bantuan retailer atau pengecer memiliki posisi kunci dalam pemasaran yang efektif hasil produk bajakan. Olsen \& Granzin (1992) juga mengatakan bahwa tanggung jawab para pengecer dalam memiliki kesadaran memberantas pembajakan merupakan bagian yang sangat besar proporsinya dalam upaya membangun jejaring (network) dan mempengaruhi kemamuan para dealer untuk mensukseskan implementasi strategi anti pembajakan dalam mengontrol arus barang dari produsen ke konsumen (Bush et al., 1989; Harvey, 1987; and Harvey \& Ronkainen, 1985). Dengan demikian, upaya yang paling efektif adalah pendekatan pengusaha pemegang HKI membangun kerjasama yang baik dengan para pengecer dan dealer untuk memperkecil penyebaran produk bajakan (Olsen and Granzin, 1992).

\section{PENUTUP}

Perkembangan yang sangat pesat di bidang teknologi mendorong munculnya produk-produk innovatif yang kaya dengan sentuhan intelektual. Akibatnya adalah banyak produk yang dipasarkan untuk kepentingan konsumen akhir di kaitkan dengan proteksi HKI. Persoalan mulai muncul ketika banyak produk yang berkaitan HKI menjadi produk-produk unggulan di pasar. Kenyataan ini dimanfaatkan oleh para spekulan mencari keuntungan dengan cepat melalui usaha pembajakan produk tersebut. Padahal melakukan pembajakan produk adalah tindakan kriminal karena tindakan itu merupakan pelanggaran HKI. Pembajakan produk saat ini sudah merupakan masalah besar karena bisnis ini sudah menjamur di pasar internasional terutama di negara Asia Timur dan Eropa Timur seperti China, Asia Tenggara, India, Rusia, Bulgaria dsbnya. Banyak ahli menyebutkan bahwa penyebabnya ada berbagai macam aspek, bisa karena aspek budaya, aspek ekonomi dan sosial. Saat ini, produk bajakan sudah menjamah mulai dari produk mewah dan mahal seperti jam tangan Rolex, sampai ke produk populer untuk kebutuhan sehari-hari (Olsen \& Granzin, 1992; dan Masland \& Marshall, 1990).

Penelitian di bidang pembajakan produk sudah bukan barang baru di dunia ilmu pengetahuan, terutama ilmu hukum. Namun, untuk bidang ilmu pemasaran, penelitian yang menyangkut pembajakan produk masih tergolong baru, sehingga belum menghasilkan kerangka teoritikal yang kuat baik yang menyangkut aspek permintaan maupun penawaran. Penelitian yang pernah dilakukan masih bersifat sporadis, dengan aspek variabel 
yang diteliti bermacam-macam. Penelitian di sisi permintaan tujuan utamanya adalah memetakan perilaku konsumen yang berkaitan dengan alasan dan keinginan beli mereka terhadap produk bajakan. Sedangkan pada sisi penawaran, tujuan utama penelitian yang dilakukan adalah memetakan strategi dan anti strategi pembjakan produk dengan harapan mampu memberikan solusi memperkecil ruang gerak pembajakan produk.

Terutama penelitian pada sisi penawaran, peneliti melakukan investigasi yang menyangkut strategi pembajakan. Menurut Harvey \& Ronkainen (1985); dan Delener (2000), ada 4 macam strategi yang dilakukan pembajak berskala internasional untuk masuk ke pasar produk bajakan, dan berbagai macam anti strategi pembajakan juga telah diimplementasikan dan diteliti tingkat efektifitasnya dalam membendung ruang gerak produk bajakan. Dari hasil penelitian Olsen \& Granzin (1992), mereka mengindentifikasikan bahwa penerapan strategi anti pembajakan oleh pemilik HKI atau pabrikan resmi tanpa melibatkan para perantara/agen dan pengecer, upaya membrantas produk bajakan tidak akan efektif.

Di samping itu, upaya pemberantasan pembajakan produk nampaknya masih memerlukan jalan yang sangat panjang meskipun kerjasama internasional di bawah koordinasi WTO telah dilakukan. Hal ini karena menyangkut sistem nilai di sebagian negara di dunia, terutama Asia, yang nampaknya masih dalam proses perdebatan terutama pada perbedaan pandangan kultural "Barat' dan 'Timur". Oleh karenanya, pemberantasan produk bajakan oleh pelaku domestik yang jumlahnya sangat banyak di kawasan Asia masih jauh dari harapan. Para pembajak domestik ini biasanya tidak memiliki pemahaman HKI sehingga tidak sadar kalau telah melakukan pelanggaran hukum. Para pembajak domestik di kawasan Asia kebanyakan para wiraswastawan alamiah (bukan keluaran pendidikan bisnis formal) yang berlatar belakang pendidikan rendah, dan didukung pula oleh nilai-nilai budaya setempat yang mengutamakan kepentingan bersama daripada kepentingan perorangan atau kelompok, sehingga HKI yang merefleksikan pengakuan hak monopoli individual atau kelompok tidak didukung oleh sistem nilai masyarakat setempat.

\section{DAFTAR PUSTAKA}

Alcock, L., Chen, P. \& Ching, H. M., Hodson, S. et al. (2003) ,'Counterfeiting: Tricks and Trends,' Journal of Brand Management, vol. 11, no. 2, pp. 133-136.

Anonymous (2003), 'Insight: Mantaining the Anti-Counterfeiting Momentum,' Managing Intellectual Property, London, p.1 
Alback, P. G. (1988), 'Economic Progress Brings Copyright to Asia,' Far Eastern Economic Review, vol. 139, no. 9, pp. 62-63.

Ang, S. H., Cheng, P. S., Lim, E. A. C. \& Tambyah, S. K. (2001), 'Spot the difference: consumer responses towards counterfeits,' Journal of Consumer Marketing, vol. 18, no. 3, pp. 219-235.

Bamossy, G. \& Scammon, D. L. (1985), 'Product Counterfeiting: Consumers and Manufacturing Beware,' Advances in Consumer Research, vol. 12, Hirshmen, E. C. \& Holbrook, M. B. (eds), Association for Consumer Research, pp. 334-339.

Bamossy, G. \& Scammon, D. L. (1984), 'Counterfeiting Counterfeits: A World Wide Problem: What is the role of channel members!' a paper presented at the third Cescomirm International Conference on Distribution, Nov. 15.

Benghozi, P. J. \& Santagata, W. (1998), 'Market Piracy in the Design-based Industry: Economics and Policy Regulation,' Working Paper was presented at the International Seminar, "The Economics of Copying and Counterfeiting", ICARE, December 3-4, Venice, pp. 1-24.

Bloch, P. H., Bush, R. F. \& Campbell, L. (1993), 'Consumer Accomplices in Product Counterfeiting, A Demand Side Investigation,' Journal of Consumer Marketing, vol. 10, no. 4, pp. 27-36.

Bush, R. F., Bloch, P. H. \& Dawson, S. (1989), 'Remedies for Product Counterfeiting,' Business Horizon, January-February, pp. 59-65.

Callan, B. (1998), 'The Potential for Translantic Cooperation on Intellectual Property in Asia, Working Paper, The Barkeley Roundtable on the International Economy, available: http://www.ciaonet.org/wps/cab02/cab02.html

Chan, A., Wong, S. \& Leung, P. (1998), 'Ethical beliefs of Chinese consumers in Hong Kong,' Journal of Business Ethics, vol.17, no. 11, pp. 1163-1170.

Chakraborty, G., Alfred, A. T., and Bristol, T. (1996), 'Exploring Consumers' Evaluations of Counterfeits: The Roles of Country of Origin and Ethnocentrism' in Advances in Consumer Research, vol. 23, pp. 379-384.

Chaudhry, P. E. and Walsh, M. G. (1996), 'An assessment of the impact of counterfeiting in international markets: The Piracy Paradox Persists,' The Columbia Journal of World Business, Fall, pp. 34-48. 
Chaudhry, P. E. \& Walsh, M. G. (1995), 'Intellectual Property Rights. Changing Levels of Protection Under GATT, NAFTA and the EU,' The Columbia Journal of World Business, Summer, pp. 81-92.

Choi, E.K (2004), "Mixed Markets with Counterfeit Producers," Choi, E. Kwan and James Hartigan (eds.) Handbook of International TradeEconomic and Legal Analysis of Trade Policy and Institutions, Volume 2, Oxford: Blackwell Publishing, 2004, 427-458.

Chow, D.C.K. (2004), 'Counterfeiting in China and its Effect on US Manufacturing,' Written Testimony, available: http://www.govt.off.senate.govt./files/ 042004chow.pdf

Cooner, K. R. \& Rumelt, R. P. (1991), 'Software Piracy: An Analysis of Protection Strategies,' Management Science, vol. 37, no. 2, pp. 125-139.

Cordell, V. V., Wongtada, N. \& Kieschnik, Jr., R. L. (1996), 'Counterfeit Purchase Intentions: Role of Lawfulness Attitudes and Product Traits as Determinants,' Journal of Business Research, vol. 35, pp. 41-53.

Coriat, B. \& Orsi, F. (2002), 'Establishing a new intellectual property rights regime in the United States. Origin, content and problems,' Research Policy, vol. 31, pp. 1491-1507.

Crisp, W. (1993), 'Fighting Back Against Counterfeiters,' Business Eastern Europe, Nov. 23, pp. 1-2.

d'Astous, A. \& Gargouri, E. (2001), 'Consumer evaluations of brand imitations,' European Journal of Marketing, vol. 35, no. 1/2, pp. 153167.

Delener, N. (2000), 'International Counterfeit Marketing: Success Without Risk,' Review of Business, spring, pp. 16-20.

Feinberg, R.M. \& Rousslang, D.J. (1990), 'The Economic Effect of Intellectual Property Right Infringements,' the Journal of Business, vol. 63, no. 1, pp. 79-90.

Fereshti N. D. (2003), 'Pelaku Pembajak vs Konsumsi Product Bajakan,' Pikiran Rakyat, available: http://www.pikiranrakyat.com/cetak/0703/16/0804.htm

Field, J. R. B. (2000), 'An Empirical Investigation of Consumers' Perceptions and Purchase Intentions of Counterfeit Products: A MeansEnd Chain Analysis,' A PhD Dissertation, Mississippi State Uni- 
versity, available: http:// wwwlib.umi.com/ dissertations/ preview all/ 9991310.

Gabella, G. \& Picasso, M. D. (1995), 'PC Software Industry Lost \$8.08 Billion To Pirates In 1994. Piracy Rate in the US Declines,' Information \& Management, vol. 29, pp. 285-288.

Ganguli, P. (2000), 'Intellectual Property Rights. Imperative for the knowledge industry,' World Patent Information, vol. 22, pp. 167-175.

Glass, A. J. \& Saggi, K. (2002), 'Intellectual property rights and foreign direct investment,' Journal of International Economics, vol. 56, pp. 387-410.

Globerman, S. (1988), Addessing International Product Piracy,' Journal of International Business Studies, Fall, pp. 497-504.

Harvey, M. (1988), 'A New Way to Combat Product Counterfeiting,' Business Horizon, Jul-Aug, pp. 19-28.

Harvey, M. G. \& Ronkainen, I. A. (1985), 'International Counterfeiters: Marketing Success Without the Cost or The Risk,' Columbia Journal of World Business, vol. 20, Fall, pp. 37-45.

Harvey, P. J. \& Walls, W. D. (2003), 'The Revealed Demand for Pirate Goods: Profit Analysis of Experimental Data,' International Journal of Management, vol. 20, no. 2, pp. 194-201.

Helpman, E. (1993), 'Innovation, 'Imitation, and Intellectual Property Rights,' Econometrica, vol. 61, pp. 1247-1280.

Higgins, R.S. \& Rubin, P.H. (1986), 'Counterfeit Goods,' Journal of Law and Economics, vol. 29, no. 2, pp. 211-230.

Husted B. W. (2000), 'The impact of national culture on software piracy,' Journal of Business Ethics, vol. 26, pp. 197-211.

International AntiCounterfeiting Coalition (2002), 'Get the Facts on Fakes! The Economic Impact of Product Counterfeiting,' available: http:// www.iacc.org/ economic.html.

Jacobs, L., Samli, A. C. \& Jedlik, T. (2001), 'The Nightmare of International Brand piracy, Exploring Defensive Strategies,' Industrial Marketing Management, vol. 30, 499-509.

Jayakar, K. P. (2003), 'Cross Sectoral Differences in Intellectual Property Enforcement in Developing Countries: The Role of State-Industry Linkage,' the Information Society, vol. 19, pp. 155-169. 
Jennings, J.S. (1989), 'Trademark Counterfeiting: An Unpunished Crime,' the Journal of Criminal Law and Criminology, vol. 80, no. 3, pp. 805-841

Johnson, J. M. (2001/2002), 'Solving China's counterfeiting problem, Managing Intellectual Property, no. 15, 4.

Kapferer, J. N. (1992), 'Strategic Brand Management: New Approaches to creating and Evaluating Brand Equity,' The Free Press, New York.

Kau, A. K., Rinnie, H. \& Swinyard, W. R. (1990), 'The Morality of Software Piracy: A Cross Cultural Analysis,' Journal of Business Ethics, vol. 9, no. 8, pp. 655-664.

Lai, K. K. Y. \& Zaichkowsky, J. L. (1999), 'Brand Imitation: Do the Chinese have different views?' Asia Pacific Journal of Management, vol. 16, pp. 179-192.

Lai, E. L. C. (1998), 'International intellectual property rights protection and the rate of product innovation,' Journal of Development Economics, vol. 55, pp. 133-153.

Lai, E. L. C. \& Qiu, L. D. (2003), 'The North's intellectual property rights standard for the South?' Journal of International Economics, vol. 59, pp. 183-209.

Lynch, S. (2002), 'Commercial Counterfeiting,' Paper prepared for Trade Inspections Conference, October 23, pp. 1-23.

Mandhachitara, R., Smith, T. \& Blois, K. (2000), 'Thailand's Counterfeit Dilemma,' Working Paper, ANZMAC 2000 Visionary Marketing for the $21^{\text {st }}$ Century: Facing the Challenge.

Mansfield, E., Schwartz, M. \& Wagner, S. (1981), 'Imitation cost and patents; and empirical study,' Economic Journal, vol.91, pp. 907-918.

Maskus, K. E. (1997), 'The International regulation of Intellectual Property,' working paper, IESG Conference 'Regulation of International Trade and Investment', University of Nottingham, Nottingham, UK

McDonald, G. M. \& Zepp, R. A. (1988), 'Ethical Perceptions of Hong Kong Chinese Business Managers,' Journal of Business Ethics, vol. 7, pp. 835-845.

McDonald, G. M. \& Roberts, C. (1994), 'Brand piracy, The Problem that Will not Go Away,'Journal of Product and Brand Management, vol. 3, no. 4, pp. 55-65. 
Marron, D. B. \& Steel D. G. (2000), 'Which countries intellectual property? The case of software piracy,' Economic Inquiry, vol. 38, no. 2, pp. 159-174.

Masland, T. \& Marshall, R. (1990), 'A Really Nasty Business,' Newsweek, vol. 116, Nov. 5, pp. 36-37,43.

Mitchell, V.W. \& Papavassiliou, V. (1997), "Exploring consumer confusion in the watch market,' Marketing Intelligence and Planning, vol. 15, no. 4, pp. 164-172.

Miller, N. D. L. (1999), 'Consumer misbehaviour: Why people buy illicit goods,' Journal of Consumer Marketing, vol. 16, no. 3, pp. 273287.

Muncy, J. A. \& Vitell, S. J. (1992), 'Consumer Ethics: An Investigation of the Ethical Beliefs of the Final Consumer,' Journal of Business Research, vol. 24, no. 4, pp. 297-311.

Nash, T. (1989), 'Only Imitation? The rising cost of counterfeiting,' Director, May, pp. 64-69.

Nia, A. \& Zaichkowsky, J. L. (2000), 'Do Counterfeits devalue the ownership of luxury goods?' Journal of Product and Brand Management, vol. 9, no. 7, pp. 485-497.

Nill, A. \& Shultz II, C. J. (1996), 'The Source of Global Counterfeiting,' Business Horizon, Nov-Dec, pp. 37-42.

Olsen, J. E. \&Granzin, K. L. (1992), 'Gaining Retailers' Assistance in Fighting Counterfeiting: Conceptualization and Empirical Test of a Helping Model,' Journal of Retailing, vol. 68, Spring, pp. 90-111.

Paula, S. (1986), 'Foreign Product Counterfeiting,' Vital Speeches of the Day, April 14, pp. 2-6.

Rallapalli, K. C., Vitel, S. J., Wiebe, E. A. \& Barnes, J. H. (1994), 'Consumer Ethical Beliefs and Personality Traits: An Exploratory Analysis,' Journal of Business Ethics, vol. 13, pp. 487-495.

Rapp, R. T. \& Rozek, R. P. (1990), 'Benefit and Cost of Intellectual Property Protection in Developing Countries,' Journal of World Trade, vol. 24, no. 5, pp. 75-102.

Pinkerton, L. F. (1990), 'Due Diligence in fine art transactions,' Case Western reserve Journal of International Law, vol. 22, Winter, pp. 1-29.

Phau, I., Prendergast, G. \& Chuen, L. H. (2000), 'Profiling brand-piracyprone consumers: An exploratory study in Hongkong's clothing in- 
dustry,' Journal of Fashion Marketing and Management, vol. 5, no. 1, pp. 45-55.

Simone, J. T. (1999), 'Countering Counterfeits,' The China Business Review, Jan-Feb, pp. 12-19.

Shore, B., Venkatachalam, A. R., Solorzano, E., Burn, J. M., Hassan, S. Z. \& Janczewski, L. J. (2001), 'Softlifting and piracy: behaviour across cultures,' Technology in Society, vol. 23, pp. 563-581.

Shultz, C. \& Saporito, B. (1996), 'Protecting Intellectual Property: Strategies and Recommendations to Deter Counterfeiting and Brand Piracy in Global Market,' Columbia Journal of World Business, Spring, pp. 18-28.

Tom, G., Garibaldi, B., Zeng, Y. \& Pilcher, J. (1998), 'Consumer Demand for Counterfeit Goods,' Psychology \& Marketing, vol. 15, no. 5, pp. 405-421.

Vagg, J. \& Harris, J. (2000), 'False Profits: Why Product Counterfeiting is Increasing,' European Journal on Criminal Policy and Research, vol. 8, pp. 107-115.

Vithlani, H. (1998), 'The Economic Impact of Counterfeiting,' published on the responsibility of the Secretary General of Organisation for Economic Co-operation and Development (OECD), Head of Publication Service, France

Vitel S. J. \& Muncy, J. (1992), 'Consumer Ethics: An Empirical Investigation of Factors Influencing Ethical Judgments of the Final Consumer,' Journal of Business Ethics, vol. 11, pp. 585-597.

Wada, T. (1996), 'Brand -name demand brings more fakes. Smuggler improve quality and tactics, confound afficials,' Nikkei Weekly, vol. 34, no. 1, available: http ://satellite.Nikkei.co.jp lenews /TNW /back/42TNWCOVER3.html.

Ward, J., Loken, B. \& Hasapopoulos, T. (1986), 'The influence of physical similarity on generalization of affect and attribute perceptions from national brands to private label brands,' in Shimp, T.A. et al (Eds), American Marketing Educators' Conference, American Marketing Association, Chicago, IL, pp. 51-60.

Wee, C. H., Tan, S. J. \& Cheok, K. H. (1996), 'Non-price determinants of intention to purchase counterfeit goods,' International Marketing Review, vol. 12, no. 6, pp. 13-46. 
Wilkie, R. \& Zaichkowsky, J. L. (1999), 'Brand Imitation and its Effects on Innovation, Competition, and Brand Equity,' Business Horizon, Nov-Dec.

Wijk, J. V. (2002), 'Dealing with Piracy: Intellectual Asset Management in Music and Software,' European Management Journal, vol. 20, no. 6, pp. 689-698.

Yao, J.T (2005), 'Counterfeiting and an Optimal Monitoring Policy,' European Journal of Law and Economics, vol. 19, pp. 95-114. 